\title{
RELATION OF SOILS AND GROUND COVER VEGETATION IN EVEN-AGED PINE STANDS OF CENTRAL ALBERTA ${ }^{1}$
}

\author{
P. K. HERINGA ${ }^{3}$ AND R. G. H CORMACK \\ $A B S T R A C T$
}

The present paper describes the ground vegetation of even-aged pine stands in West Central Alberta on six different sites and attempts to relate the ground vegetation to soil conditions.

\section{INTRODUCTION}

The present paper is an initial step in an attempt to relate ground vegetation to soil conditions and tree growth in pure pine stands. The area selected for special study lies in the Whitecourt region which is situated about eighty miles northwest of Edmonton. Due to the occurrence of repeated fire, wide areas in this region support even-aged stands of jack pine (Pinus banksiana), lodgepole pine (Pinus contorta) and jack pine - lodgepole pine hybrids $(4,6)$. The general elevation of this region is 2250-2700 feet above sea level.

Since the early studies of Cajander (2) in Europe, many investigators have made use of ground cover plants for forest-site classification. Spilsbury and Smith (7) have used this approach in their study of forest site types of the Pacific Northwest, while most recently Illingworth and Arlidge (5) have related ground vegetation to forest site in the South Central Interior of British Columbia. In descending order of site quality their major lodgepole pine sites are: Cornus-moss type, Calamagrostis type, Calamagrostis-Vaccinium scoparium type, Calamagrostis-Arctostaphylos type, Arctostaphylos-lichen type.

\section{METHODS}

During the summer of 1960 , six even-aged stands, $65-70$ years old were selected within a radius of six miles near Whitecourt. Five, $1 / 10$ acre plots with a density of 500 trees per acre were marked out in each stand on more or less level ground in six different soils. Where possible another five plots in each stand with a density of 600 trees per acre were also selected. A hole, 4 feet deep was dug near the centre of each $1 / 10$ acre plot and notes were made from each profile on horizon, structure and acidity. Samples of soil of the two horizons forming the main rooting zone were collected and analyzed later in the laboratory as to texture according to the method described by Bouyoucous (1). An estimate was made of the percentage of ground covered by each plant species in the six soil types.

\footnotetext{
1 This is a cooperative project between the Alberta Forest and the Research Council of Alberta.

${ }^{2}$ Peter K. Heringa obtained his B.S.A. and M.S.A. in Wageningen, The Netherlands and migrated to Canada in 1950 . He worked a number of years with the Eastern Rockies Forest Conservation Board and as soil surveyor with the Research Council of Alberta. He now has joined the science Service, Canada Dept. of Agriculture, St. John's, Nfld.

${ }^{3}$ Professor of Botany, Uniq. of Alta., Edmonton, Alta. Biographical reference, For. Chron. $29(3) .1953$.
} 


\section{Observations And Results}

The historical background of these 60-70-year-old pine stands is much the same on all six sites. Growth was fair for the first 12-19 years, slowed down for a few years, improved for another short period as the result of fire, slowed down again, then stagnated for the last 25-30 years. All six stands have originated as the result of fire and thus represent an early intermediate stage in coniferous forest succession.

The ground cover consists of a mixture of feather mosses, a great variety of "Reindeer moss" lichens, a thin scattering of low shrubs and a relatively small number of herbaceous flowering plants. Floristically all six stands conform to the stage of coniferous forest succession designated Feather moss-Reindeer moss-Blueberry (Hypnum-Cladonia-Vaccinium) type (3). The general scheme of the distribution of herbaceous and shrub species in relation to soils after that of Wilde et al. (8) is presented in Table 1. A brief description of the six different soil sites with grey wooded or podsolized grey wooded development follows.

\section{Site 1. Coarse outwash}

This site was situated on a level gravel bank about 50 feet above the McLeod River, under fairly uniform soil and drainage conditions.

The area under investigation supports almost a pure stand of pine (dominant height 65 feet) over the greater part of the bank with the exception of the southern end where an increase in finer soil material over the gravel is accompanied by a marked increase in aspen regeneration. The pine vary in density from 500-600 per acre on the eastern part of the bank and 650-800 per acre in the western part. The following soil layers were recognized.

$A_{0}, 1 / 2$ inches; partly decomposed organic matter and needles.

$A_{2 p}, 3$ inches; ashy grey, gravelly sandy loam with single grain structure.

$\mathrm{B}_{\mathrm{p}}, 8$ inches; loose, brown gravelly sandy loam.

$\mathrm{B}_{3}, 24$ inches; layers of yellowish brown gravelly loamy sand.

Low bushy ericaceous plants (Vaccinium myrtilloides and V. vitis - idaea) are the most abundant shrubs on this site while the herbaceous layer on the whole is poorly developed (Table I).

The moss layer is thin and composed chiefly of Hypnum crista-castrensis, and occasionally Hylocomium splendens and Dicranum undulatum. Small patches of lichens are common; they include Cladonia spp. and also Peltigera spp.

Site 2. Loamy Sand

Similar to site 1 , this site supports an almost pure stand of pine (dominant height 66 feet) ranging in density from 500-900 trees per acre.

The soil is alluvial in origin with signs of shallow local wind-sorting at the top. Soil moisture conditions are influenced by silty horizons to about a depth of 4 feet, below which point there is an increase in the coarse sand fracture with bands of dark organic material.

$\mathrm{A}_{\mathrm{o}}, 1$ inch; partly decomposed organic material.

$\mathrm{A}_{2}, 3$ inches; loose light grey loamy sand.

$\mathrm{B}_{2}, 8$ inches; loose reddish brown loamy sand with some gravel.

$B_{3}, 36$ inches; layers of sand, and loamy sand with some gravel.

$B_{c n}$, at 48 inches or deeper. 
TABLE 1

Ground Cover Plants Characteristic Of Different Soll Types In EvenAged Pine Stands (Numbers Represent The Relative Estimated Percentage Ground Cover IN The 6 Sires As Follows: (1) Less Than 1\% (2) $1-5 \%$; (3) $5-10 \%$; (4) $10-15 \%$; (5) $15-20 \%$ ).

\begin{tabular}{|c|c|c|c|c|c|c|}
\hline \multirow[t]{2}{*}{ Species } & \multicolumn{6}{|c|}{ Relative Density of Species } \\
\hline & $\begin{array}{c}1 \\
\text { coorse } \\
\text { outwash }\end{array}$ & $\begin{array}{c}2 \\
\text { loamy } \\
\text { sand }\end{array}$ & $\begin{array}{c}3 \\
\text { Ioamy } \\
\text { till }\end{array}$ & $\begin{array}{c}4 \\
\text { loamy } \\
\text { sandy } \\
\text { silt }\end{array}$ & $\begin{array}{c}5 \\
\text { clay } \\
\text { till }\end{array}$ & $\begin{array}{c}6 \\
\text { silty } \\
\text { loam }\end{array}$ \\
\hline \multicolumn{7}{|l|}{ Shrubs and Small Trees } \\
\hline Alnus crispa & 2 & 1 & & 2 & & 5 \\
\hline Arctostaphylos uva-ursi & 1 & 2 & 1 & 1 & 1 & \\
\hline Amelanchier alnifolia & & 1 & & & & \\
\hline Betula occidentalis & & & 1 & & & \\
\hline Betula pumila var. glandulifera & 1 & 1 & 1 & 1 & 1 & 2 \\
\hline Cornus stolonifera & 1 & & & & & \\
\hline Larix laracina & & 1 & & & & \\
\hline Ledum groenlandicum & 2 & 2 & 5 & 3 & 5 & 2 \\
\hline Lonicera glaucescens & & 1 & 1 & & 1 & \\
\hline Ribes hudsonianum & & & & & & 2 \\
\hline Rosa acicularis & 2 & 1 & 1 & 2 & 1 & 2 \\
\hline Rubus pubescens and R. strigosu & us 1 & 1 & & 1 & & 2 \\
\hline Salix sp. & 1 & 1 & 1 & 1 & 1 & 2 \\
\hline Shepherdia canadensis & 2 & 2 & 1 & 1 & & \\
\hline Vaccinium membranaceum & & 1 & 1 & & 1 & \\
\hline Vaccinium myrtilloides & 3 & 2 & 2 & 2 & 2 & 2 \\
\hline Vaccinium vitis-idaea & 4 & 3 & 2 & 2 & 3 & \\
\hline Viburnum edule & 1 & 1 & 1 & 1 & 1 & 2 \\
\hline \multicolumn{7}{|l|}{ Herbaceous Plants } \\
\hline Achillea lanulosa & & 1 & & & & \\
\hline Actaea rubra & & & & & & 2 \\
\hline Aralia nudicaulis & & 1 & & 2 & & 2 \\
\hline Arnica cordifolia & & & 1 & & & \\
\hline Aster spp. & & 1 & 1 & 1 & 1 & 2 \\
\hline Calamagrostis rubescens & & & & & 1 & 2 \\
\hline Campanula rotundifolia & 1 & 1 & 1 & 1 & & \\
\hline Comandra lucida & & 1 & & 1 & & \\
\hline Cornus canadensis & 2 & 2 & 2 & 2 & 2 & 3 \\
\hline Elymus innovatus & $\overline{1}$ & 2 & $\overline{1}$ & 1 & 1 & \\
\hline Epilobium angustifolium & 1 & 1 & 1 & 1 & 2 & 2 \\
\hline Fragaria glauca & 1 & 1 & 1 & 1 & 1 & 4 \\
\hline Galium boreale & 1 & 1 & & 1 . & & \\
\hline Lathyrus ochroleucus & 1 & 1 & 1 & 1 & 1 & \\
\hline Linnaea americana & 2 & 2 & 2 & 2 & 1 & 3 \\
\hline Maianthemum canadense & 2 & 2 & 1 & 2 & 1 & 2 \\
\hline Oryzopsis asperifolia & 1 & & & & & \\
\hline Petasites palmatus & & 1 & 2 & & 1 & 2 \\
\hline Pyrola spp. & 2 & 1 & 1 & 1 & & 2 \\
\hline Vicia americana & 1 & 1 & & & & \\
\hline Viola sp. & 1 & & & 1 & & \\
\hline Total Number of species & 25 & 31 & 23 & 25 & 20 & 20 \\
\hline
\end{tabular}


This site supports a total of 31 different species, the largest number of ground cover species of all six sites. However, the density of both shrubs and herbaceous plants is just as low as in site 5 which supports a total of only 20 species. (Table I).

The moss layer is thin and discontinuous and dominated by Hypnum crista-castrensis, with the occurrence of Dicranum undulatum and Hylocomium splendens. Small patches of Cladonia spp. and Peltigera spp. are common.

\section{Site 3. Loamy Till}

This site situated on gently rolling land supports a relatively uniform and fairly open stand of pine (dominant height 61 feet) and a few aspen. Stand densities range from 500-900 trees per acre in irregular patterns.

The soil consists of silty loam to clay loam developed on glacial till with local variations in texture of the upper horizons which suggests a possible overlay of lighter waterlaid materials.

$A_{0}$, 2inches; partly decomposed organic material.

$\mathrm{A}_{2}, 2$ inches; grey brown platy mottled silty loam.

$\mathrm{AB}, 4-6$ inches; yellowish brown, small nuciform mottled silty loam.

$\mathrm{B}_{2}, 8$ inches; brown, massive blocky clay loam.

$\mathrm{B}_{3}, 36$ inches; very dark brown blocky clay loam.

$B_{\text {ca }}$, at 40 inches on till.

Labrador tea (Ledum groenlandicum) is by far the most abundant shrub, while the three species of Vaccinium occur in fair abundance. The herbaceous layer is low in the number of species and poorly developed (Table I).

The moss layer is well developed and consists mainly of Hypnum cristacastrensis, Sphagnum spp. and to a lesser extent small patches of Hylocomium splendens and Dicranum undulatum. Lichens occur but are less conspicuous and include species of Cladonia and Peltigera.

\section{Site 4. Loamy sandy silt}

Unlike the stands of pine previously described for sites, 1, 2 and 3 , the stand developed on this site is relatively open and consists of vigorously growing pine (dominant height 74 feet) and some aspen. There are indications that this low density was reached at a rather early age. The soil can be described as a loamy sand of alluvial parent material varying in soil moisture with the presence of shallow layers of silty material.

$A_{0}, 1 \frac{1}{2}$ inches; semi-decomposed organic material.

$A_{2}, 1-3$ inches; loose light grey sand to loamy sand, with small stones.

$A_{3}, 1$ inch, loose yellowish brown loamy sand with a few small stones.

$\mathbf{B}_{2}, 8$ inches, loose, yellowish brown loamy sand.

$\mathrm{B}_{3}, 40$ inches, yellowish brown loamy sand with silt bands and some mottling just above the silt bands.

$B_{c a}$, at 50 inches often found just above a layer of silt.

The ground vegetation is moderately developed and shows no distinguishing features (Table I).

The moss layer is fairly thin and discontinuous and consists mainly of Hypnum crista-castrensis and scattered patches of Dicranum undulatum and Hylocomium splendens. Lichens occur in patches and consist mainly of Cladonia spp. and of Peltigera spp. in more shaded areas. 


\section{Site 5, Clay till}

Unlike the other stands previously described the stand on this site is not pure pine (dominant height 53 feet) but includes occasional pockets of young aspen and some spruce seedlings. There is also a scattering of spruce saplings of variable height throughout the stand. Tree density ranges from 500-1200 trees per acre. In the more dense areas, the pine are spindly and decidedly shorter and there is an excessive number of dead trees.

The soil is a grey wooded clay loam to clay, developed on glacial till. $A_{0}, 2$ inches; semi-decomposed organic material.

$A_{1}, 0-2$ inches; dark brown, silty loam, some stones, partly mottled.

$\mathrm{A}_{2}, 4$ inches; light brownish grey, mottled, platy, silty loam.

$\mathrm{B}_{2}, 7$ inches; very dark brown, massive blocky clay, some stones.

$\mathrm{B}_{3}, 30$ inches; dark yellowish brown massive blocky clay.

$B_{c a}$ at 45 inches; dark yellowish brown clay, loam, with lime pockets on till.

This site supports only 20 shrub and herbaceous species and with the exception of labrador tea, the density of the ground cover plants is strikingly low (Table I).

Mosses are abundant and form a well developed layer consisting of Hypnum crista-castrensis and Hylocomium splendens, with scattered patches of lichens, mainly Peltigera spp.

\section{Site 6. Silty Loam}

Because of the relatively small area and extreme variability in tree density, only one plot of pure pine (dominant height 78 feet) could be located on this site. This stand is distinguished by the occasional occurrence of large clumps of willow and a dense underbrush of alder.

The soil profile shows about three feet of variegated alluvial deposits on glacial till.

$A_{0}, 1 \frac{1}{2}$ inches; semi-decomposed organic material.

$\mathrm{A}_{2}, 2$ inches; dark grey brown, platy silty loam.

$A_{3}, 13$ inches; pale brown somewhat mottled small nuciform silty loam.

$\mathrm{B}_{2}, 6$ inches, dark yellowish brown massive blocky clay loam.

$\mathrm{B}_{3}, 5$ inches; layers of sand and gravel.

$\mathrm{B}_{4}, 12$ inches; dark grey brown layers of clay and sand on till.

Table 1 shows that alder (Alnus crispa) is the most abundant shrub or small treee on this site, and although the number of ground cover species is as low as in site 5 the density of the ground vegetation is by far the highest of all the soil types.

The moss layer is patchy and consists of Hypnum and Hylocomium species, interspersed with clumps of lichens consisting of species of Cladonia and Peltigera.

Growing conditions for lodgepole pine appeared to be poorest in site 5 (clay till) with a dominant tree height of 53 feet and only a little better in site 3 (loamy till) with a dominant tree height of 61 feet. Site 1 (coarse outwash) and site 2 (loamy sand) with dominant tree heights of 65 feet and 66 feet respectively were average, while site 4 (loamy sandy silt) showed fairly good growth with a dominant tree height of 74 feet. Site 6 
(silty loam) showed the best growth with a dominant tree height of 78 feet.

Although the soils described for the six different sites show considerable variability, the ground cover plants which they support show with minor exceptions a marked resemblance. Coltsfoot (Petasites palmatus) occurs only in the loamy clay and clay soils, while Buffalo-berry (Shephedia canadensis) is absent on these heavier soils but present on the lighter, sandier soils. Low bush blueberry (Vaccinium myrtilloides) occurs on all six sites in almost the same abundance, while bog cranberry (Vaccinium vitis-idaea) decreases in abundance with an increase in finer soil particles and is absent on the silty loam type (Site 6). However, at this time, the lack of any striking differences in composition and density of the ground vegetation makes it impossible to assign the name of any one ground cover plant or combination of plants to serve as indicators of a definite soil-forest type.

\section{REFERENCES}

1. BOUYOUCOUS, G. J. 1951. A calibration of the hydrometer method for making mechanical analysis of soils. J. Amer. Soc. Agron. 43, 434-438.

2. CAJANDER, G. K. 1926. The theory of forest types. Acta Forestalia Fennica. 29.

3. CORMACK, R. G. H. 1953. A survey of coniferous forest succession in the eastern rockies. Forestry Chron. 29, 218-232.

4. HALIIDAY, W. E. D. 1937. A forest classification for Canada. Canada Dept. of mines and resources, forest service bull. 89.

5. ILINGWORTH, K, and J. W. C. ARLIDGE. 1960. Interim report on some forest site types in Todgepole pine and spruce-alpine stands. Research Notes. British Columbia Forest Service. $35,1-44$.

6. MOSS, E. H. 1949. Natural pine hybrids in Alberta. Can. J. Research, C. 27, 218-229.

7. SPILSBURY, R. H. and D. S. Snith. 1947. Forest site types of the Pacific Northwest. British Columbia Forest Service. Technical Publication T. 30, 1-46.

8. WILDE, S. A., P. B. WHITFORD, and C. T. YOUNGBERG. 1948. Relation of soils and forest growth in the driftless area of southwestern Wisconsin. Ecology, 29, 173-180.

\section{(Continued from Page 251)}

Associations o fProfessional Foresters. Although many non-forestry graduates have made outstanding contributions, in the long run the best forest research should come from leading graduates of recognized University programs in forestry who by virtue of post-graduate study or experience have specialized in the scientific aspects of forestry. Such men can make contributions to forest science based upon real understanding about the field in which their studies must be applied. Another important group of forest scientists is made up of University graduates in allied fields who have specialized knowledge pertinent to one or more branches of forestry and are in a position to make significant contributions to our knowledge about some aspects of forestry. Obviously, members of this group are not foresters and cannot become so unless they satisfy the requirements for registration in a Provincial Forestry Association or secure a Bachelor's degree in Forestry.

Local Sections of the C.I.F. can play an important part in maintaining and improving professional knowledge. Meeting themes and speaker's topics should deal with professional or scientific aspects of Forestry. Standing Technical Committees also can bring together forest scientists and general

(Continued on Page 312) 